\title{
Determining the Technical Competencies of Construction Managers in the Malaysia's Construction Industry
}

\author{
Hairuddin Mohammad ${ }^{1, a}$, Siti Khalijah Yaman ${ }^{1}$, Fadzil Hassan ${ }^{2}$ and Zulhabri Ismail ${ }^{2}$ \\ ${ }^{1}$ Faculty of Civil and Environmental Engineering, Universiti Tun Hussein Onn Malaysia, 86400 Parit Raja, Johor, \\ Malaysia \\ ${ }^{2}$ Centre for Construction Project and Infrastructure Management, Universiti Teknologi Mara, 40450 Shah Alam, \\ Selangor, Malaysia
}

\begin{abstract}
It is a common conviction that project management, construction management, and site management are the tools for improving the performance of the construction project as a whole. Notwithstanding the similarities and differences between all of them, construction management which consists of off-site and on-site activities is deemed to have the major influence on the succession of a project. Consequently, a competent construction manager is required throughout the particular phase to shape the construction stability and geared up to complete the proposed development as according to several common objectives. Nonetheless, a competent construction manager will not just appear "out of the blue", they need to be teach, train, and develop in order to equip them with comprehensive competency sets. For that reason, education, training, and continuing professional development (CPD) are in place to provide the required knowledge, skills, and abilities. However, the debates on the inadequacy and problems on current construction management programs are continued to impede Malaysia's construction environment. It has been observed that lack of term of reference on the technical competency for construction manager is became the major setback. Hence, this paper tries to unfold the circumstances by offering a preliminary countermeasure to alleviate the situation through analysis of literatures. It was found that, the associated central phenomenon is believed to be explored holistically with the inclusion of multi layered thematic analysis as a tool to assist the exploration processes. Then, the respective outcomes from the analysis are deemed to be ready for subsequent phases, for instance the validation phase.
\end{abstract}

\section{Introduction}

Construction industry became renowned as one of the important industry throughout the globe. It was one of the contributors for a country's growth domestic product (GDP). Further, it appeared that construction industry act as a multiplier for other important industries such as manufacturing, agriculture, mining and even services sector to move forward especially in term of providing completed functional facilities (i.e. buildings and infrastructures). Their spills over effects are no doubt benefited many facets of construction related personnel across all level of positions. Regrettably, the progression of Malaysia's construction industry was hampered by a considerable number of problems. It was observed that the frequent theme of exceeding time and budget, not

\footnotetext{
${ }^{a}$ Corresponding author : hairuddin81@gmail.com
} 
according to the specifications, excessive wastages, and subpar quality was particularly due to the contractors' fault which primarily occurred during the physical implementations of a construction project [1-4].

Currently, there are 67,833 of contractors (as of 2014) in the construction industry and 57,785 of construction managers (CM) (as of 2011) registered with the Construction Industry Development Board (CIDB) $[5,6]$. Since the CM is the key person in construction and generally representing the contractors, their contributions towards the successfulness of construction projects were undeniable, particularly during the construction phase. Given that construction phase exploits a lot of resources (manpower, materials, money, and machines), a competent $\mathrm{CM}$ is needed in order to manage those resources and geared up to achieve organizational objectives. Unfortunately, it was believed that only a few is qualified and fully trained CM since their (the competent CM) existence is in the dark. Even within nearly 58,000 construction managers [7], their level of competency and qualification is unknown [8]. Adding up salt to the wound, continuous critiques from past scholars on untiring degradation towards construction education and training does not helped to alleviate the previous problems [9-11]. Gaps particularly on knowledge and skills are still persisting, notwithstanding the level of offerings [12]. Furthermore, the absence of CM competency standard in the latest National Occupational Skills Standard (NOSS) indirectly impeded the appalling situation [13]. Hence, the particular mismatches together with problems of poor site management has resulted in many construction projects' failures and end up derailed from their true goals. Appropriately, the issue underpinning the lack of training and competent construction managers is the dearth of recognized and established term of reference for construction managers' competency provided within the industry.

Therefore, the author tries to unfold the predicament by focusing on CM technical competency. Since it is clear that faster proactive action should be in the training and education's pipeline, a spotlight into visible and ease of teachable technical competency is paramount $[8,14-16]$. Treating it as a central phenomenon, critical preliminary countermeasures are pursued to give ways for subsequent phases of the research exploration. Thus, culmination of views from past researchers were taken seriously by peeling off the CM technical competency's term, reviewing what others have done, and it will be followed by building up the relevant maiden stage through acceptable multiple layered thematic analysis.

\section{Construction Managers Technical Competencies}

\subsection{Construction management}

In reflection to Malaysia's preferred contractual approach, a general type of construction project life cycle will be taken into consideration. A general construction project will undergo several important phases throughout its life cycle (see Figure 1) [17-21]. Each phase has its own target and they may use different resources, together with different management approach. On top of that, generally each phase falls under different term of management, namely project management, construction management, and site management. Notwithstanding the similarities and differences between all of them, construction management which consists of off-site and on-site activities is deemed to have the major influence on the succession of a project.

As according to Koskela [20], construction management process is "where the detail designed is transformed into a construction/fabrication plan and into day-to-day coordination and control of processes on site or in a factory". Likewise, due to the consumption of a lot of resources (money, materials, machines, and manpower) during that phase alone [23], the determination of profit or losses are more prevalent; either on behalf of client or contractor.

Moreover, by referring to a general construction delivery and beside the existence of client and designer as a key player during the construction phase, contractor plays a significant role. Their contribution may start as early as the tendering or bidding process until the physical product complete as planned. Aware on the demanding nature of the construction phase, therefore it necessitates an allaround capable managers to lead and serve as moderators between each parties involved [24-26]. 
Thus, it requires a good management effort which normally leads by a construction manager in order to integrate all manageable items and transform it into an end solid product. For that reason, it was agreed that all construction managers should comprehensively have adequate competencies; a determinant to the successful of a construction project. In general, construction manager should have hard (technical) and soft (behavioural) competency to ensure that they are professionally fit for the construction world [27]. It is a 'must' because they are among the forefront in their respective field, where a lot of responsibilities is at stake in today's fast changing construction pace. Therefore, in order to summarise the culmination of common characteristics of construction management, subsequent table (refer Table 1) might be sufficient.

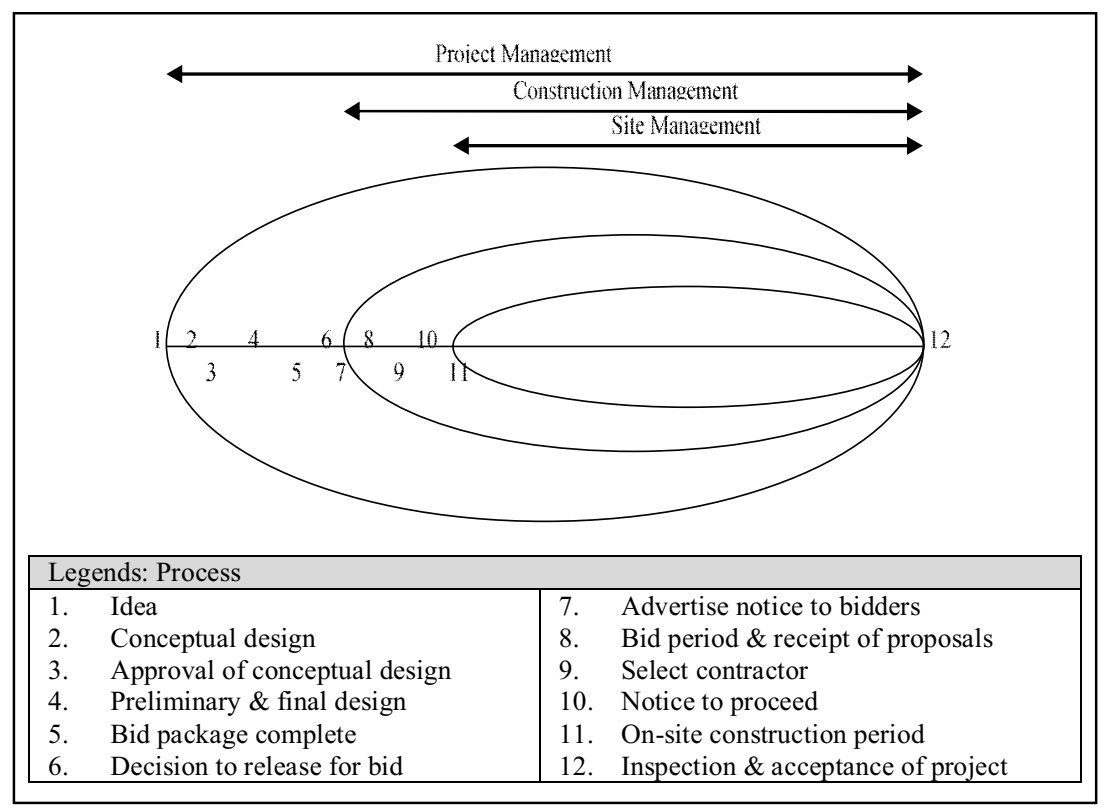

Figure 1. Overall phases of a general construction project life cycle.

\subsection{Competency}

Competency or competence for some others is getting much attention in a past few decades, especially in the literature of management strategy during 1990s [28]. It was understood that the term is usually associated with training and educational fields. Hassan et al. [12] and Stoof et al. [27] were both agreed that the concept of competency is frequently used in the area of education including training and Continuing Professional Development (CPD). The particular concept is deemed to be the underlying formula to develop a new or improvisation of an existing educational method. In his work, McDaniel [28] came out with a model which shows the magnitude of competency identification as a critical consideration for CM curriculum design. Besides, Stoof et al. [27] added that competency is not limited only for educational purposes but the significance of the concept was also appreciated by business organizations through their human resource development (HRD) programs.

A preliminary study shows that skills, knowledge, and abilities (including attitudes) became the primary elements when discussing what is inside the "competency" [12, 29, 32, 33]. Additionally, based on the communal findings, it is obvious that the concept of competency underpinned the definition propounded by researchers. Besides, most of the researchers agreed that competency need to be discussed along with its intended usage, function, and amid its appropriate contexts, in order to have the most suitable meanings. Thus, in reaching the mutual concept of competency amid numerous deliberations, the attribute-based approach (work oriented) seems spot-on and was agreed by most of 
the researchers. Thus, the following diagram (see Figure 2) illustrates the concept of competency as according to Hassan et al. [12] and several others, and it will became the concern of this paper.

Table 1. Summary of several characteristics and approach to CM.

\begin{tabular}{|c|l|l|l|c|}
\hline No. & Characteristics & \multicolumn{1}{|c|}{ Details } & \multicolumn{1}{|c|}{ Approaches } & Leads by \\
\hline 1 & Period & Have defined start and end & Need to be managed properly & \\
\hline 2 & Product/service & One of its kind, unique & $\begin{array}{l}\text { According to client's } \\
\text { requirements }\end{array}$ & Construction \\
Manager \\
\hline 3 & $\begin{array}{l}\text { Critical } \\
\text { components }\end{array}$ & $\begin{array}{l}\text { Time, cost, quality, scope, } \\
\text { resources }\end{array}$ & $\begin{array}{l}\text { Need to be balance and in } \\
\text { equilibrium }\end{array}$ & $\begin{array}{l}\text { Need to be managed properly } \\
\text { maney, manpower, }\end{array}$ \\
\hline 5 & Environment & $\begin{array}{l}\text { Complex, uncertain, } \\
\text { demanding }\end{array}$ & $\begin{array}{l}\text { Inclusion of risk management, } \\
\text { change management, etc. }\end{array}$ & \\
\hline 6 & Phases & $\begin{array}{l}\text { From bidding to } \\
\text { acceptance of project }\end{array}$ & Need to be managed properly & \\
\hline
\end{tabular}

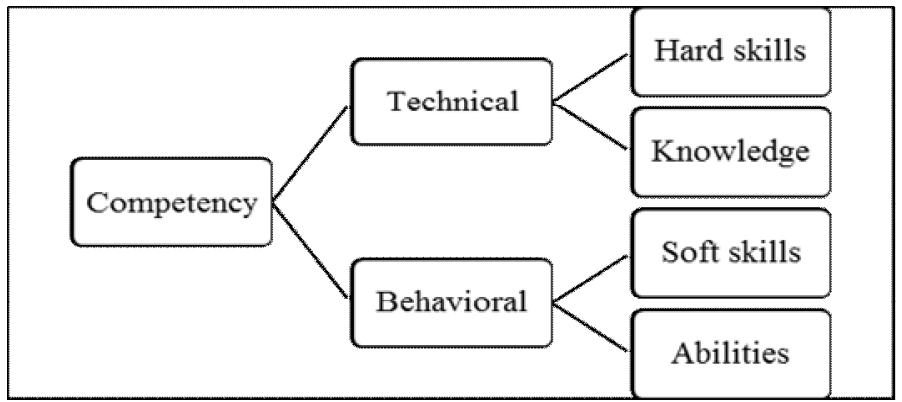

Figure 2. Concepts of competency as according to Hassan et al. [12].

Therefore, it is understandable that competency itself covers a large area. So as the identification of comprehensive technical competency and behavioural competency for construction manager, it requires a considerable work endeavour. For that reason, in accordance with the work of Stoof et al. [27] and Le Deist et al. [26] where they lend support from Spencer and Spencer in 1993, Hartle in 1995, and Parry in 1996, they were mutually agreed on the "visible" part of competency which comprises of skills and knowledge. It is accepted that skills and knowledge are noticeable and also teachable, where skills and knowledge are categorized as hard competency and can be develop through training and education. In a serious note, between both types of competency (i.e. technical and non-technical), technical competency is a vital consideration in order to match individual to their job scopes, but regrettably it was often being ignored by the common competency approaches [16]. To a certain extent, the superfluous focus made towards non-technical competency (i.e. behaviours and attitudes) by early developers of competency models were gradually diminished the important fixtures of technical competency. On the other hand, due to differentiate between skills and knowledge, Egbu's definitions were brought forward [34] :

a) On knowledge: "the ideas, wisdom and facts managers acquire through experience, theory and practice; the acquisition of which gives them an ability to understand".

b) On skills: "the activities or patterns of behaviour which managers undertake in order to accomplish a given desired outcome".

Based on the Egbu's definitions and the construction manager's realm, knowledge is everything to be learned and known [34]. It is an overall information gathering paradigm, where every associated knowledge elements need to be embedded (within the contexts of training and education). Further, for a certain knowledge that associated with a kind of activity, basically the learners knew about "know- 
how", but physical realisation-wise is not yet implemented. Moreover, "know-how" might be a combination of a number of knowledge in order to complete the entire "know-how". Meanwhile, skills required practices, actions and conducts, where basically uses human anatomy (i.e. physical structure such as hand and leg) and things. Similarly to knowledge, a mixture of skills may need in order to accomplish a given task. Here, it is clear that knowledge and skills compliments each other. Knowledge on most occasions became a primary element and as a basis for establishment of skills.

Therefore, with regard to technical competency of construction manager, both contexts (i.e. knowledge and skills) were utmost important. Thus, drawing from the works of several researchers, technical competency attributes which related to construction management were identified. Generally, the construction management functions such as planning, organising, staffing, coordinating, and controlling were considered as technical attributes. It was able to be derived from analysis of the key tasks or work outputs, where a pure construction activity that involves process, methods, materials, systems, and equipment comes into perspective (see summary on Figure 3).

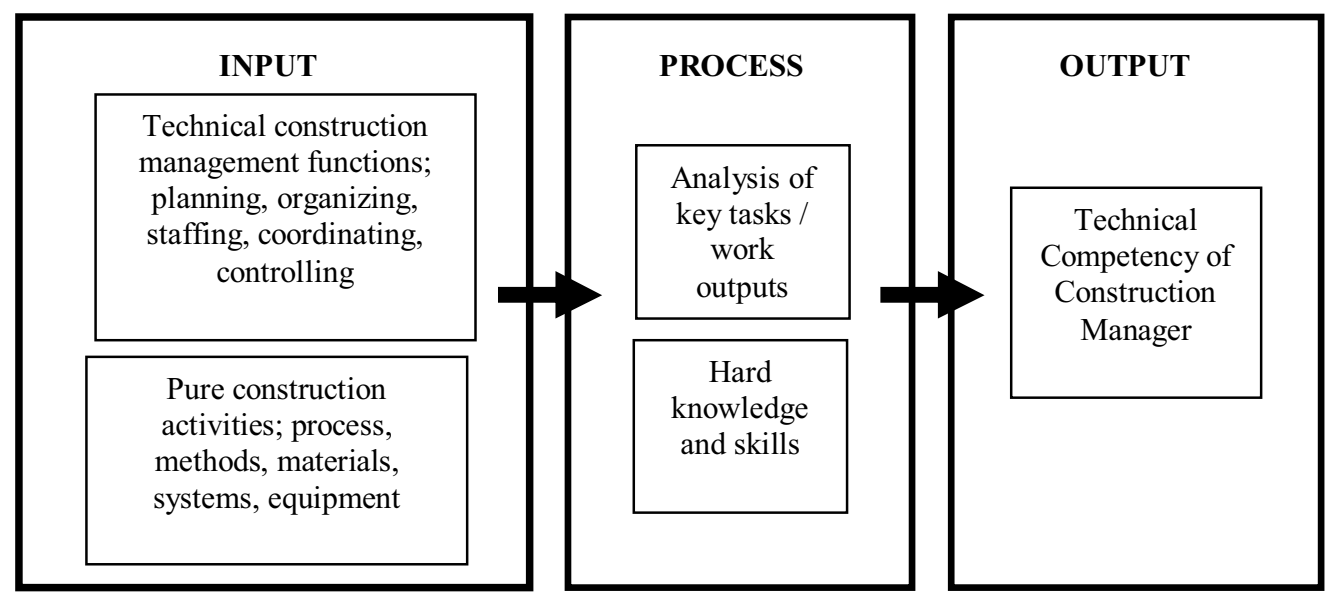

Figure 3. Identifying processes of technical competency for construction manager.

\section{Past Research on Construction Manager's Competency}

Research on CM competency is not new and much likely it will keep evolved from time to time. Drawing from the works of [32, 8-41] their main motive to reconsider the competency of construction manager is quite similar. Based on the problems, purposes, and actions taken, most of them stressed on the inadequacy of the construction management training/education in coping with fast-changing nature of the construction industry, which in turn resulting the damaging nature of construction project as a whole. However, the authors do not intend to deliberate on the issue of training/education as a whole, but only embarked on the quest of establishing the preliminary stage, which are identifying the technical competency for CM. Based on the previously cited researchers (as in the beginning of the topic), reviewing the similar quest is of paramount concern of this paper. Set aside their full context of epistemology's anchorage, their moves to choose positivism, constructivism, or pragmatism approaches is not aptly judged by the authors.

Collectively, all researchers were agreed that $\mathrm{CM}$ is representing the contractors. Only a tiny discrepancy was observed on behalf of [24, 38]. Riggs [38] postulated that the CM are representing the clients, meanwhile Love et al. [24] did not specify the exact organisation should the CM worked with, but stressed that CM may represents all facet of construction practitioners' organisations. This issue are debatable, and to some extent involves the semantic inquiry in term of the position title itself. Not favourable to the issue, the paper follows the majority of past researchers' standpoint; by insisting the $\mathrm{CM}$ representing the contractors. 
As far as educational research is concerned, literature review is a must, where cases were built from ground up in order to fully understand the research topic (as a preliminary stage). Mutually, the authors observed that all researchers were compiling related competency for CM based on previous literatures. By referring Riggs [38] and Egbu [32] the move was apparent. Meanwhile, the rest was compiling from related institutional documents such as the American Council for Construction Education (ACCE), the American Institute of Constructors' (AIC), the California State University, and the Aalborg University [30, 36, 41, 43]. On the other hand, Arditi et al. [42] are compiling from a combination of past literatures and the Construction Management Association of America (CMAA), the American Institute of Architects (AIA), and the Associated General Contractors of America (AGC). Aside, there are two researches that use focus group interviews to gather CM's competency in the first place [42, 45]. Besides compiling activities, there were some attempt to cluster the competency from the ground up through inclusion of construction project stages [40, 45], abiding to predetermine cluster from institutional documents or past research [24, 30], and differentiation according to the nature of the competency itself [25].

In a nutshell, the authors believed that the previous research was providing a context rich competency for $\mathrm{CM}$ as according to their predetermined scopes. However, there was also evidence that the compilation was way beyond the boundary of construction management that being discussed previously by the authors. Additionally, proper iteration of competency either technical or nontechnical was nowhere to be found or rather bland. Thus, pondering if the similar approach were taken by the authors and were applied towards Malaysia's construction industry that yet having established competency for CM, devastating effects would be around the corner. Confusion on the underlying generic competency for CM (especially the technical competency) might appear and it will further mess up the curricular design of related education/training. Thus, the authors assert appropriate compilation of technical competency for $\mathrm{CM}$ through preliminary stage of the research. Inclusion of stringent screening process is deemed to help the process.

\section{Multi Layered Thematic Analysis and Clustering of Technical Competency}

Guided by the written texts of Creswell [44, 45], preliminary identification of CM's technical competency is ideally follows the central phenomenon approach. It is also the approach taken by vast majority of past researchers. Literatures derived mostly by books, journals, and legitimate documents provide established listing of competency, where context-rich information is gathered. It may later on accompanied by qualitative (i.e. interview as validation and value added information), and/or quantitative (questionnaire survey as testing of theory and generalisation). Fully aware on the nature of compiling the CM's technical competency, the authors posits that credible qualitative-like approach is deemed appropriate Thus, multi layered thematic analysis is considered suitable as an approach to collect, sieve, and analysis towards the appropriate literatures by focusing on preliminary-selected themes before moving on to latter processes. Every layer regarding the analysis will become screening net, which at the end of the layer, comprehensive and meaningful data were extracted.

On the other hand, the authors also see the integration of clustering efforts might as well helps in term of organisation and significantly ease the latter processes of data. However, these were also became an issue, especially if their substance is questionable. Basically, there are two approaches that usually being considered by past researchers; clustering from the ground up (already being touched previously), and clustering through subsequent analysis of data (mostly by quantitative inquiry). The former is at ease since following the established predetermined clusters which maintaining meaningful clusters' title, meanwhile the latter are relying on computational mathematical formula to segregate the data into new found clusters. For instance, attempts to categorise competency into several clusters by using Principal Component Analysis (through Varimax Rotation Method with Kaiser Normalization). More often than not, the authors observed newly created clusters' title at the end of the particular analysis. Without doubting the approach, however the authors believed that the move was to a certain extent unleashed incomprehensiveness and requiring more translational works (e.g. 
tweaking) especially during education/training design development (i.e. from competency sets to realisation of education/training module).

Therefore, as far as the paper is concerned, adoptions of multi layered thematic analysis together with appropriate clustering efforts were indeed beneficial towards preliminary identification of the said central phenomena. Multiple considerations' loop accompanying the process while gathering information from literatures is believed to produce exhaustive, holistic, and reliable outcomes (i.e. CM's technical competency) [7]. Thus, the following figure (see Figure 4) outlined the overall concept adopted by the authors. It can be seen that there are three major layers consists of construction management phase's boundary, identification of CM's technical competency, and preliminary clustering efforts according to valid past literature. All layers had been discussed appropriately in the preceding section of the paper. Nevertheless, there are added quality measures being imposed to each and every one of competency items before it was eventually finalised. Things such as reassessment and improvisation of cluster's categories might plausibly conduct in order to maintain cohesive and conciseness, as long as meaningful clustering approach were attained.

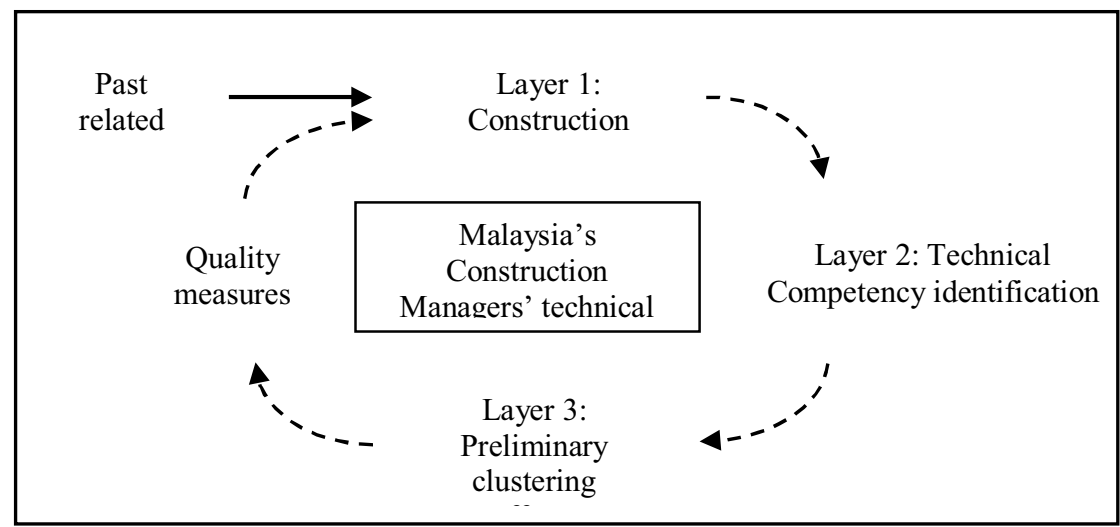

Figure 4. Multiple loop for assisting multi-layered thematic processes.

\section{Conclusion}

It was observed that in order to offer primary counter measure for problems depicted in the beginning of the paper, a thorough investigation on technical competency of construction manager would be essential. Due to the fact that the competency of construction manager is commonly being researched form time to time, abundance of technical competency was expected. Helped by delving into vast availability of literatures, the central phenomenon is believed to be explored holistically. Additionally, the inclusion of multi layered thematic analysis as a tool to assist the exploration may indeed fruitful. Purposely-built nets of construction management phase, technical competency identification, and proper clustering guidance is reckoned to efficiently sieve the information. Nevertheless, since the nature of required technical competency which may not come with "one size fits all" necessitates the need of local inputs. This is where subsequent undertaking follows, for instance, consideration of inputs from "academia-industry" namely the academicians and construction practitioners through other inductive or deductive approaches (e.g. interviews and surveys). It was apt since our construction environment is changing very fast and they are the ones who encountered those phenomena the first hand. To sum up, both competency sets (i.e. technical and non-technical) are indeed needed for a construction manager to be competent, despite different technique of construction methods were applied. However, these pragmatic moves to give a focus on the generic technical aspect will positively bridge the knowledge gaps and further assisting succeeding endeavours, at least in Malaysia. 


\section{References}

[1] H.A. Rahman, M.A. Berawi, A.R. Berawi, M.O.O. Mohamed and I.A. Yahya, Delay mitigation in the malaysian construction industry, J. of Const. Eng. and Manag., 132, 125-133, (2006).

[2] M. Sambasivan and Y.W. Soon, Causes and effects of delays in malaysian construction industry, International Journal of Project Management, 25, 517-526, (2007).

[3] Unit Penyelarasan Pelaksanaan, Pengurusan Projek Sektor Awam, Jabatan Perdana Menteri, Kuala Lumpur, (2013).

[4] National Audit Department Malaysia, Auditor General's Report 2014: Activities of the Federal Ministries/Departments and Management of the Government Companies (Series One), Kuala Lumpur, (2014).

[5] Construction Industry Development Board Malaysia, Buletin Statistik Pembinaan Suku Tahunan 2014, Kuala Lumpur, (2014).

[6] Construction Industry Development Board Malaysia, Maklumat: Statistik Pendaftaran Personel, CIDB News, 23, (2011).

[7] Construction Industry Development Board Malaysia, Maklumat: Statistik Pendaftaran Personel. CIDB News, 1, (2011).

[8] S. Yaman, A. Abdullah, H. Mohammad and F. Hassan, Technical competency of construction manager in malaysian construction industry, Applied Mechanics and Materials, 773-774, 10531059, (2015).

[9] A.H.A. Bakar, Construction in the developing world: Issues on indigenous contractors, Contextual Issues of the Built Environment in Malaysia, Pulau Pinang, Penerbit Universiti Sains Malaysia, (2009).

[10] A.R. Ibrahim, M.H. Roy, Z. Ahmed and G. Imtiaz, An investigation of the status of the Malaysian construction industry, Benchmarking, 294-308, (2010).

[11]L.F. Tong, Identifying essential learning skills in students' Engineering education, HERDSA Conference Proceedings, (2003).

[12]F. Hassan, M. Maisham, S.M.I. Khan, S.A.S. Alwi and H. Ramli, Competencies, skills, and knowledge of quantity surveying graduates, The Quantity Surveying International Convention, (2010).

[13]NOSS Division, Dept. of Skills Development, National Occupational Skills Standard (NOSS) Registry 2014, Ministry of Human Resource, Malaysia, Kuala Lumpur, (2014).

[14]G.T. Haugan, Project Management Fundamentals: Key Concept and Methodology, Management Concepts, Vienna, (2006).

[15]H.S. Cooke and K. Tate, Project Management, McGraw-Hill, New York, (2005).

[16]R.S Mansfield, Building competency models: Approaches for HR professionals, Human Resource Management, 35, 7-18, (1996).

[17]C.F. Gray and E.W. Larson, Project Management: The Managerial Process, McGraw-Hill, New York, (2008).

[18]R. Burke, Project Management: Planning and Control Techniques, John Wiley and Sons, London, (2003).

[19]D.W. Halpin, Construction Management, John Wiley and Sons, Hoboken, (2006).

[20]L. Koskela, Application of the New Production Philosophy to Construction, Technical Report No. 72, Stanford University, (1992).

[21] G.J. Ritz, Total Construction Project Management, McGraw-Hill, New York, (1994).

[22] S.S.M. Isa, A Study on Roles and Tasks of Construction Managers in Malaysian Construction Industry, Universiti Teknologi Mara Malaysia, Shah Alam, (2007).

[23]R.U. Farooqui and M. Saqib, Desirable attributes and skills for graduating construction management students, Associated Schools of Construction Proceedings, (2010).

[24]P.E. Love and N.S. Haynes, Construction managers' expectations and observations of graduates, Journal of Managerial Psychology, 16, 579-593, (2001).

[25] S.U.R. Toor and G. Ofori, Developing Construction professionals of the 21st century: Renewed vision for leadership, Journal of Profes. Issues in Eng. Edu. and Practice, 279-286, (2008). 
[26]F.O.D.L. Deist and J. Winterton, What is competence?, Human Resource Development International, 8, 27-46, (2005).

[27]A. Stoof, R.L. Martens, J J.G.V. Merriënboer and T. J. Bastiaens, The boundary approach of competence: a constructivist aid for understanding and using the concept of competence, Human Resource Development Review, 1, 345, (2002).

[28]D. McDaniel, Developing an integrated curriculum model for construction management education, Journal for Workforce Education and Development, 1, Article 2, (2005).

[29]P. Hager and A. Gonczi, What is competence?, Medical Teacher, 18, (1996).

[30] S. Hackett, Educating for competency and reflective practice: Fostering a cojoint approach in education and training, Journal of Workplace Learning, 13, 103-112, (2001).

[31]R. Dogbegah, D. Owusu-Manu and K. Omoteso, A principal component analysis of project management competencies for the ghanaian construction industry, Australasian Journal of Construction Economics and Building, 11, 26-40, (2011).

[32]C.O. Egbu, Skills, knowledge and competencies for managing construction refurbishment works, Construction Management and Economics, 17, 29-43, (1999).

[33]R.S. Mansfield, Building competency models: Approaches for HR professionals, Human Resource Management, 35, 7-18, (1996).

[34] S.O. Wandahl and L.W. Ussing, construction management engineer education with focus on competencies required by the construction industry, Conference Proceeding W089 - Special Track 18th CIB World Building Congress, (2010).

[35]P.T. Mullin and A.N. Williams, using skills gap analysis in construction management to stimulate a demand led model of curriculum, Conference Proceeding W089 - Special Track 18th CIB World Building Congress, (2010).

[36] Y.H. Ahn, H. Kwon, A.R. Pearce and H. Shin, Key competencies for US construction graduates: an exploratory factor analysis, ASC Proceedings of the 46th Annual Conference, (2010).

[37]N. Lee, R. Ponton, A. Jeffreys and R. Cohn, Analysis of industry trends for improving undergraduate curriculum in construction management education, 47th ASC Annual International Conference Proceedings, (2011).

[38]L.S. Riggs, educating construction managers, J. Constr. Eng. Manage., 114, 279-285, (1998).

[39]D.E. Gunderson, J.W. Ra, H. Schroeder and H.R. Holland, needs assessment - a construction management Bachelor of Science degree program in Alaska, Journal of Construction Education, 7, $86-96,(2002)$.

[40]A.J. Hauck and B.J. Jackson, Design and implementation of an integrated construction management curriculum, ASC Proceedings of the 41st Annual Conference, (2005).

[41]C. Souder and D.M. Gier, What does the construction industry expect from recent construction management graduates?, ASC Proceedings of the 42nd Annual Conference, (2006).

[42]D. Arditi and D. Ongkasuwan, Technical notes: Duties and responsibilities of construction managers: Perceptions of parties involved in construction, Journal of Construction Engineering and Management, 135, (2009).

[43]B.L. Benhart and M. Shaurette, Establishing new graduate competencies: ensuring that construction management curriculums are delivering "job-ready" employees, 47th ASC Annual International Conference Proceedings, (2011).

[44]J.W. Creswell, Qualitative Inquiry and Research Design: Choosing Among Five Approaches, Sage Publications, United Kingdom, (2007).

[45]J.W. Creswell, Educational Research: Planning, Conducting, and Evaluating Quantitative and Qualitative Research, Pearson, Ohio, (2008). 